\title{
日本発行の科学技術雑誌の調査 (1)電子ジャーナル化の状況
}

\section{Study on scholarly journals published in Japan}

(1)Number of electronic journal titles

時実 象一 1

\section{TOKIZANE Soichi ${ }^{1}$}

1 愛知大学（干441-8522 愛知県豊橋市町畑町1-1） E-mail : Tokizane@aichi-u.ac.jp 1 Aichi University (1-1 Machihata-cho Toyohashi-shi, Aichi 441-8522)

\section{目次}
1.はじめに
2. 調査方法と結果

2.1 杂倠誌リストの収集

2.2 統合雑誌リストの作成

2.3 科学技術医学系学術雑誌の同定

3. 電子ジャーナル化の状況

(以下後編)

4. データベースへの収録状況

4.1 国内文献データベースの収録状況

4.2 海外文献データベースの収録状況

5. まとめ

6. おわりに

1.はじめに

学術雑誌数の変遷についてのこれまでの研究に ついては倉田がまとめている11。最近ではTenopir ${ }^{2}$ は2003年のUlrichのデータ3)から，世界では18万 200誌の逐次刊行物が発行されており，そのうち4 万 3,500 誌が学術雑誌，2万1,000点が査読付き雑誌
であると報告している。さらに全点のうち3万 4,500誌がオンライン，6,500誌がCD-ROMとなって いるが，重複を除くと，電子化されている雑誌数 は3万7,500誌になろうとしている。これを査読付 き雑誌に限ると電子化されている学術雑誌数は1 万4,600点, 査読付き電子ジャーナルは1万 1,000 点 と推定している。Ulrichの掲載雑誌数はその後も増 加しており，2007年1月のオンライン雑誌数は4万 7,000誌であり，そのうち2万4,300誌が学術雑誌と されている。また学術雑誌は2006年現在約 2 万 3,000 件が発行されており, 年140万件の文献が公 開されている4）との報告がある。ただしこれらの 数字には中国や日本を含むアジアの雑誌がどの程 度網羅されているかは明らかではない。中国の電 子ジャーナル数については先に時実が報告してお り5)，9,100誌を超える学術雑誌がすでに電子化さ れている。

わが国で刊行されている逐次刊行物について は，国立国会図書館のNDL-OPACに収録されている 点数が和雑誌新聞が約 13 万件, 洋雑誌新聞が約 5 万 件となっている (2007/12/1現在) 6)。ただしこれ 
らには発行を終了したり, 名称が変更されたりし たものも含まれており，すべてが現在発行されて いるわけではない。同じく国立国会図書館が編集 している『日本科学技術逐次刊行物総覧》』では 6,798件の科学技術関係の雑誌が収録されている (2007/3/4現在) が，このうち電子化されている ものの数は明らかではない。

また，わが国で発行されている科学技術雑誌の 記事は国内外の各種文献情報データベースに収録 されているが，これらの収録状況についてはあま

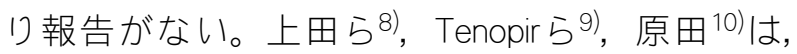
主として公表された雑誌リストにより収録状況を 報告しているが，これら雑誌リストにはすでに刊 行を中止したり, 名称が変更されたものも含まれ ており, 数が水増しされている可能性がある。一 方殿崎 ${ }^{11}$ は実際にPubMedデータベースを検索して おり,より実態に近いデータといえる。またわが 国の雑誌に限定されていないが各種データベース

表1 データベース作成機関から直接入手した 2005年の収録誌リスト

\begin{tabular}{|l|r|l|l|}
\hline \multicolumn{1}{|c|}{ 提供機関 } & \multicolumn{1}{c|}{ 誌数 } & 対象データベース & \multicolumn{1}{|c|}{ 収録対象 } \\
\hline 科学技術振興機構 & 6,387 & JSTPlus & 科学技術全般の世界の文献 \\
\cline { 3 - 4 } & & JMEDPlus & 国内医学文献 \\
\hline 医学中央雑誌刊行会 & 2,283 & 医学中央雑誌 & 国内医学文献 \\
\hline 日本医薬情報センター & 417 & JAPIC & 国内医薬文献 \\
\hline
\end{tabular}

の雑誌収録調査も行われている ${ }^{12)-15) 。 ~}$

本報告では，2005年時点でわが国において発行 されている科学技術関係の雑誌の総数と，そのう ち電子化されているものについて調査するととも に，国内外の各種文献情報データベースに収録さ れている数についても調査し，わが国での科学技 術雑誌出版の現状を明らかにしようとするもので ある。この調査にはわが国の学会誌で海外出版社 から出版されている雑誌も含まれる。なお本報告 は筆者の口頭発表16)のデータをさらに詳しく調 査・解析して更新したものである。なお本稿では 「雑誌」の語を逐次刊行物（serials）と同等の意味 で用いている。

\section{2. 調査方法と結果}

\section{1 雑誌リストの収集}

調査の対象となる雑誌リストを作成するに当た り，わが国の主要データベース作成機関にご協力 いただき，2005年時点での日本発行雑誌の記事収 録実績リストをExcelデータにて入手した。各リス

トは表1のとおりである。 これに加えて，データベース・サイトおよび電子

表2 Webから入手した国内データベースの収録誌リスト

\begin{tabular}{|c|c|c|c|c|c|}
\hline 提供機関 & 対象データベース & 誌数 & 収集日 & 収録対象 & URL \\
\hline 日外アソシエーツ & ジャーナルインデックス & 27,498 & 2006/8/1 & $\begin{array}{l}\text { 日本発行の各種雑誌 (国立国会図書館収集の } \\
\text { 雉誌他) }\end{array}$ & http://www.nichigai.co.jp/database/jn//top.html \\
\hline \multirow{2}{*}{$\begin{array}{l}\text { 科学技術振興機構 } \\
\text { (JST) }\end{array}$} & JSTPlus & 21,200 & * & 日本および海外の科学技術関連逐次刊行物 & http://pr.jst.go.jp/db/jstplus/ \\
\hline & JMEDPlus & 10,000 & * & 日本発行の医学関連逐次刊行物 & http://pr.jst.go.jp/db/jmedplus/ \\
\hline 医学中央雑誌刊行会 & 医中誌データベース & 5,000 & ${ }^{*}$ & $\begin{array}{l}\text { 国内の大学·学協会·研究所·病院等が発行し } \\
\text { ている定期刊行物 }\end{array}$ & http://www.jamas.gr.jp/scripts/serch.asp \\
\hline $\begin{array}{l}\text { 国立情報学研究所 } \\
\text { (NII) }\end{array}$ & $\begin{array}{l}\text { Citation Database for } \\
\text { Japanese Papers (CJP) } \\
\text { 書誌 }\end{array}$ & 1,628 & $2007 / 4 / 28$ & 国内の自然科学分野の学術論文誌·学協会誌 & http://ci.nii.ac.jp/cinii/pages/cinii-db.html \\
\hline
\end{tabular}

表3 電子ジャーナル・サイト等から入手した雑誌リスト

\begin{tabular}{|l|l|r|r|l|l|}
\hline \multicolumn{1}{|c|}{ 提供機関 } & 電子ジャーナル・サイト & 誌数 & \multicolumn{1}{|c|}{ 収集日 } & 収録対象 & URL \\
\hline 国立情報学研究所 & NII-ELS学協会誌 & 1,058 & $2007 / 4 / 28$ & 国内の学協会が発行する学術雑誌 & http://ci.nii.ac.jp/cinii/pages/cinii-db.html \\
\hline 国立情報学研究所 & NII-ELS研究紀要 & 5,059 & $2006 / 9 / 17$ & 国内の大学等が刊行する研究紀要 & http://ci.nii.ac.jp/cinii/pages/cinii-db.html \\
\hline 科学技術振興機構 & J-STAGE & 387 & $2007 / 5 / 17$ & 日本の学協会発行の電子ジャーナル & http://info.jstage.jst.go.jp/data/library/journals_listja.zip \\
\hline 国立国会図書館 & WARP電子雑誌 & 1,527 & $2008 / 4 / 20$ & 日本の電子ジャーナル (リンクのみ) & http://warp.ndl.go.jp/WABibSearch.php \\
\hline
\end{tabular}


ジャーナル・サイトの公開されている収録雑誌リス トからも雑誌デー夕を収集した。これらは表2，3 のとおりである。表2の誌数は，データベースの全 期間にわたって収録されたすべての雑誌を対象と しているので，表1の誌数とは異なっている。さら に海外データベース (CA, MEDLINE, Scisearch, Scopus）に収録されている雑誌でこれらリストに 含まれていないものは随時追加した。特に国内学 協会の英文誌で海外出版社から発行されているも のは，これらリストから漏れていることが多かっ たので調査の上追加した。

\section{2 統合雑誌リストの作成}

これらのリストの雑誌レコードから統合雑誌リ ストを作成した。各リストのレコードの多くには ISSNが記載されていたので，まずこれによって統 合を行った。しかしISSNが記載されていない刊行 物も多数あり, これらのものについては誌名と発 行機関により一致したものについて統合した。誌 名の書き方にもばらつきがあり，また和文名・英 文名が不統一に使われている場合もある。あいま いなものはNDL-OPAC ${ }^{17)}$ の「一般資料の検索／申し 込み」ページおよびNACSIS Webcat ${ }^{18)}$ などによって 確認した。その過程で新たにISSNが確認できたも のもあるが，もともとISSNが付与されていない場 合も多かった。

表4 雑誌の同定例

\begin{tabular}{|c|c|c|c|c|}
\hline 例 & DB & DB のコード & 誌名 & ISSN \\
\hline \multirow{3}{*}{$\begin{array}{l}\text { 誌名が完全に一致し } \\
\text { ないもの }\end{array}$} & JST & $\mathrm{X0203 \textrm {A }}$ & すい臓 & $0913-0071$ \\
\hline & NII & AN10043798 & 脺臟 & $0913-0071$ \\
\hline & CA & & Suizo & $0913-0071$ \\
\hline \multirow{3}{*}{$\begin{array}{l}\text { 同一誌の分冊なのに } \\
\text { 別々のレコードとなっ } \\
\text { ている例 (同一誌と } \\
\text { 見なす) }\end{array}$} & \multirow[t]{3}{*}{ JST } & G0520A & $\begin{array}{l}\text { Japanese Journal of Applied } \\
\text { Physics }\end{array}$ & $0021-4922$ \\
\hline & & G0520B & $\begin{array}{l}\text { Japanese Journal of Applied } \\
\text { Physics. Part 1. Regular Papers, } \\
\text { Short Notes \& Review Papers }\end{array}$ & $0021-4922$ \\
\hline & & F0599B & $\begin{array}{l}\text { Japanese Journal of Applied } \\
\text { Physics. Part 2. Letters } \\
\end{array}$ & $0021-4922$ \\
\hline \multirow{2}{*}{$\begin{array}{l}\text { 誌名が変わったのに } \\
\text { 同一ISSNを使ってい } \\
\text { る例(別の雑誌と見 } \\
\text { なす) }\end{array}$} & \multirow[t]{2}{*}{ JST } & C0278A & Journal of Chromatography & $0021-9673$ \\
\hline & & C0278B & Journal of Chromatography A & $0021-9673$ \\
\hline
\end{tabular}

各リストには同一誌名（またはISSN）の雑誌が 収録期間の違い，発行者の違い，分冊など区別に より, 別々のレコードとなっているものもある。こ れらのうちISSNが同一のものは1件の雑誌と見な した。また逆に途中で誌名が変更されたり，分割 されたにもかかわらず，同一のISSNを使っている 雑誌もあるが, これらは異なる雑誌として数えた。 これらの調査は主としてNDL-OPACを用いた。これ ら分析の例を表4に示した。

これにより最終的に2万548件の雑誌リストが作 成できた。各レコードはISSNがあるときはISSN（才 ンラインISSNの場合もある）をキーとし，ISSNがな いときは独自のキーを付与した。またデータベー ス・電子ジャーナルの各リストのレコードにも同 一のキーを付与し，このキーによって電子ジャー ナル・サイト間，データベース間の重複を検出し た。

表5人文・社会科学系の分野

\begin{tabular}{|c|c|c|}
\hline 大分野 & コード & 分野 \\
\hline \multirow{3}{*}{ 芸術 } & ART & 美術 \\
\hline & MUS & 音楽 \\
\hline & DRA & 映画·演劇 \\
\hline \multirow{11}{*}{ 人文科学 } & EDU & 教育(科学技術系を除く) \\
\hline & LAN & 言語 \\
\hline & LIT & 文学 \\
\hline & PHL & 哲学·思想 \\
\hline & PSY & 心理学(実験·臨床系を除く) \\
\hline & REL & 宗教 \\
\hline & CUL & 文化·博物館(科学博物館を除く) \\
\hline & LIB & 図書館·文書館 \\
\hline & GEO & 地理 \\
\hline & HIS & 歴史·考古学 \\
\hline & SPT & スポーツ \\
\hline \multirow{8}{*}{ 社会科学 } & BUS & 商学·ビジネス \\
\hline & ECM & 経済·政経 \\
\hline & LAW & 法律·法政 \\
\hline & POL & 政治学.行政·国際関係·地域学 \\
\hline & LBR & 労働 \\
\hline & soc & 社会学.人間関係学·犯罪·統計 \\
\hline & wsV & 福祉 (保健福祉を除く) \\
\hline & AGR & 農業·漁業·林業（科学技術系を除く） \\
\hline
\end{tabular}




\section{3 科学技術医学系学術雑誌の同定}

このリストには人文社会芸術系の雑誌も多く含 まれている。表5に示した分野名を雑誌名もしくは 出版者名に含むものは，人文社会芸術系と見なし た。杂倠誌名等から判明しない場合は雑誌のホーム ページなどで確認した。人文社会芸術系でないも のは科学技術医学系と見なした。

次に雑誌の種別を表6の定義に従って, 主として 誌名と出版者名によって分類した。明らかでない ものについては雑誌のホームページなどで確認し た。一般に「論文誌」とは査読済み論文を掲載す る雑誌との意味であるが, 便宜上, 原著論文があ るものは「論文誌」と見なした。

論文誌を2つに分け, 学協会から発行されている 論文誌を通常の「論文誌」とした。ここでいう学 会には研究会規模のものも含まれる。一方大学か ら発行されている雑誌については発行者が「学会」

表6＼cjkstart雑誌種別と定義

\begin{tabular}{|l|l|}
\hline \multicolumn{1}{|c|}{ 雑誌種別 } & \multicolumn{2}{c|}{ 定義 } \\
\hline 論文誌 & 原著論文を主とする雑誌で主として学協会が発行するもの \\
\hline 大学等論文誌 & 原著論文を主とする雑誌で大学·研究所が発行するもの* \\
\hline 大学紀要 & 大学所属研究者の論文を掲載する雑誌 \\
\hline 研究所紀要 & 研究所所属研究者の論文を掲載する雑誌 \\
\hline 病院紀要 & 病院医師の症例·治療例等を掲載する雑誌 \\
\hline データ集 & 観測記録、データベースなど \\
\hline 会社技報 & 会社所属研究者の技術論文を掲載する雑誌 \\
\hline 大会抄録·予稿集 & 学術大会の抄録·予稿集·論文集 \\
\hline 一般雑誌 & 原著論文を含まない学術雑誌 \\
\hline 二ュース·会報 & 学協会等の会員向け記事からなる雑誌 \\
\hline 雑 & 報告書、白書、書籍シリーズ, 別冊·特集号, 書籍(単行本)など \\
\hline
\end{tabular}

“科学技術系雑誌のみに定義

表7 雑誌の分野別, 種類別の件数*

\begin{tabular}{|c|c|c|c|c|c|c|}
\hline \multirow[t]{2}{*}{ 分野 } & \multirow[t]{2}{*}{ 雑誌数 } & \multirow[t]{2}{*}{ 種別 } & \multicolumn{2}{|c|}{ 雑誌数 } & \multicolumn{2}{|c|}{ うち英文誌 } \\
\hline & & & 全体 & $\begin{array}{c}\text { 2005年 } \\
\text { 発行 }\end{array}$ & 全体 & $\begin{array}{c}\text { 2005年 } \\
\text { 発行 }\end{array}$ \\
\hline \multirow[t]{3}{*}{ 人文·社会系 } & \multirow[t]{3}{*}{7,781} & 論文誌 & 1,437 & & 26 & \\
\hline & & 大学紀要 & 4,156 & & 59 & \\
\hline & & その他合計 ** & 2,188 & & 18 & \\
\hline \multirow{4}{*}{$\begin{array}{l}\text { 科学技術. } \\
\text { 医学系 }\end{array}$} & \multirow[t]{4}{*}{12,768} & 論文誌 & 2,899 & 2,655 & 416 & 351 \\
\hline & & 大学等論文誌 & 603 & & 83 & \\
\hline & & 大学紀要 & 2,886 & & 33 & \\
\hline & & その他合計 ** & 6,380 & & 88 & \\
\hline 合計 & 20,549 & & 20,549 & & 723 & \\
\hline
\end{tabular}

*2005 年に発行されていたもの

** 表6の「論文誌」,「大学等論文誌」「大学紀要」以外のもの。

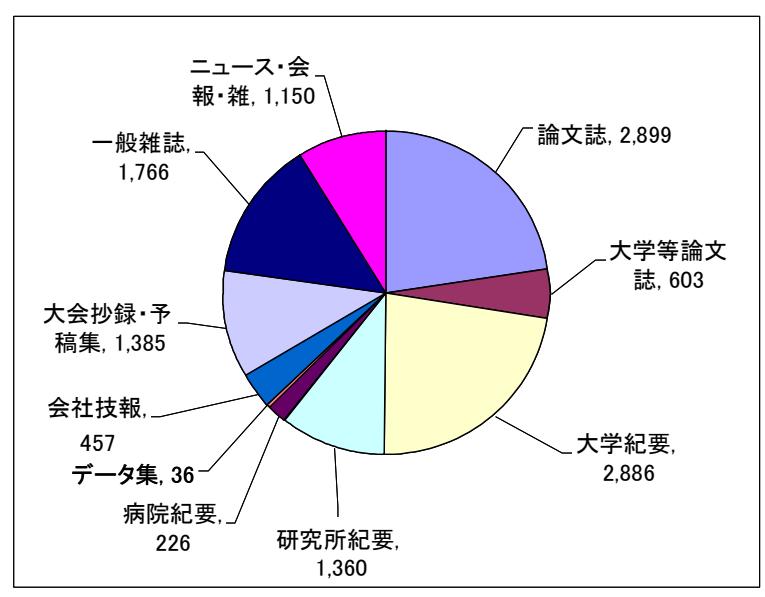

図1 科学技術医学分野の雑誌種別分布

となっているもの (例えば「関西医科大学医学会」) のみ「大学等論文誌」と見なし，それ以外は付置 研究所の雑誌も「紀要」とした。「大学等論文誌」 には研究所などが発行する論文誌も含まれる。協 会（業界団体）から発行されているものは, 原著 論文が含まれていることが確認できない場合は 「一般雑誌」に分類した。

商業出版社から発行されている雑誌は通常「一 般雑誌」としたが，独立した編集委員会が存在す る場合は「論文誌」と見なした。この結果雑誌リ ストは表7のように分類できた。すなわち科学技術 医学系においては論文誌，大学等論文誌，大学紀 要がそれぞれ2,899誌，603誌，2,886誌で，そのう ち英文誌数はそれぞれ，416誌，83誌，33誌であっ た。英文誌であるかどうかは, NDL-OPACの記載, および必要な場合その雑誌のホームページで確認 した。

\section{表8 雑誌種別の例}

\begin{tabular}{|c|c|c|c|}
\hline 種別 & ISSN & 誌名 & 発行者 \\
\hline 論文誌 & $0019-2341$ & 照明学会誌 & 照明学会 \\
\hline 大学等論文誌 & $0022-7226$ & 金沢大学十全医学会雑誌 & 金沢大学医学部十全医学会 \\
\hline 大学紀要 & $0072-4521$ & 岐阜大学医学部紀要 & 岐阜大学医学部 \\
\hline 研究所紀要 & 1349-1113 & 宇宙航空研究開発機構研究開発報告 & 宇宙航空研究開発機構 \\
\hline \begin{tabular}{|l} 
病院紀要 \\
\end{tabular} & $0287-4334$ & 小倉記念病院紀要 & 小倉記念病院 \\
\hline データ集 & $1347-3093$ & 物質·材料研究機構疲労データシート & 物質·材料研究機構 \\
\hline 会社技報 & 0372-0462 & 東芝レビュー & 東芝 \\
\hline 大会抄録·論文集 & $0288-5840$ & 日本土壤肥料学会講演要旨集 & 日本土壤肥料学会 \\
\hline 一般雜誌 & $0001-8724$ & 神経研究の進歩 & 医学書院 \\
\hline
\end{tabular}


また科学技術医学分野の杂倠誌種別の詳細は図1 のようになった。論文誌・紀要以外のもの(「その 他合計」）が多いのは，元となったデータベースの リストがこれらの資料を雑誌として含んでいたた めである。各雑誌種別の雑誌の例を表8に示す。

上記2,899論文誌についてのみ, 2005年に実際に 発行されていたかどうか確認した。その数は2,655 誌であり，うち英文誌は351誌であった。除かれた 雑誌は主として2005年時点で廃刊となっていた雑 誌である。以下の分析はこれら2,655誌を対象とし ている。

なお，これら英文論文誌351誌のうち，国内で発 行されているものは227誌, 海外出版社によって発 行されているものは124誌であった。海外出版社か ら出版されている雑誌の出版社別の内訳は図2の ようになる。

\section{3. 電子ジャーナル化の状況}

国内の主要な電子ジャーナル・サイトは表9のと おりである。また各電子ジャーナル・サイトの特 徵は以下のとおりである。

\section{(1)J-STAGE}

1999年にサービスが開始された，科学技術分野 の電子ジャーナル・サイトで, 参加学会が自分で 書誌データや公開用のPDFを作成して登載する。 PubMed, ChemPort, CrossRefなどと相互リンクし ており, Google Scholarからもリンクされている。閲

表9＼cjkstart国内の主要な電子ジャーナルサイト

\begin{tabular}{|l|l|l|}
\hline \multicolumn{1}{|c|}{ 名称 } & \multicolumn{1}{|c|}{ 提供者 } & \multicolumn{1}{c|}{ URL } \\
\hline J-STAGE & $\begin{array}{l}\text { 独立行政法人 } \\
\text { 科学技術振興機構 } \\
\text { (JST) }\end{array}$ & http://www.jstage.jst.go.jp/ \\
\hline NII-ELS & 国立情報学研究所 (NII) & http://ci.nii.ac.jp/journal/society/all.jp.html \\
\hline メデイカルオンライン & 株式会社メテオ & http://www.meteo-intergate.com/ \\
\hline PierOnline & 株式会社サンメデイア & https://www.pier-online.jp/ \\
\hline MedicalFinder & 株式会社医学書院 & http://ej.islib.jp/ejournal/ \\
\hline
\end{tabular}

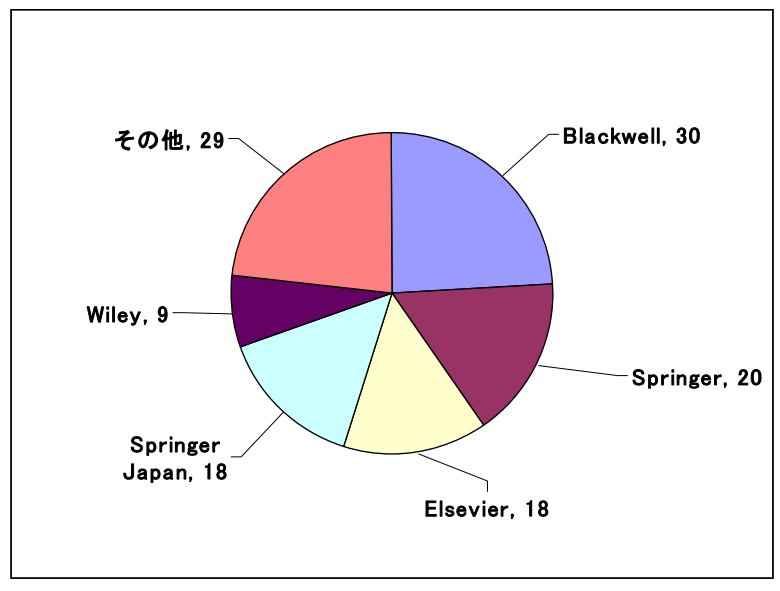

図2 海外出版社から発行されている英文誌の内訳（2005年）

覧は提供学会の購読方式によるが，無料閲覧でき るものも多い。

(2)NII-ELS

国立情報学研究所が1997年にNACSIS-ELSとして サービス開始した「電子図書館」サービスで, 学 会から入手した雑誌をスキャンによって電子化し ている。また大学の協力を得て大学紀要も電子化 して登載している。書誌・抄録データは学会の許 諾を受けてGoogle Scholarに提供されている。本文 は無料の場合もあるが有料の場合は登録が必要。

(3)メディカルオンライン

株式会社メテオが2000年から提供している医学 雑誌の電子ジャーナルで, 出版社から提供された 雑誌をスキャンにより電子化して登載している。 本文閲覽はフリーアクセス（固定料金）方式と従 量制がある。

\section{(4)PierOnline}

株式会社サンメディアが2005年から提供してい る医学・薬学出版社のための電子ジャーナル・ホ ストサービス。購読と一部売り (pay-per-view) の 両方を提供。

\section{(5)MedicalFinder}

株式会社医学書院が2007年6月より提供してい る雑誌記事閲覧検索サービス。当初はMJ-Finderと 


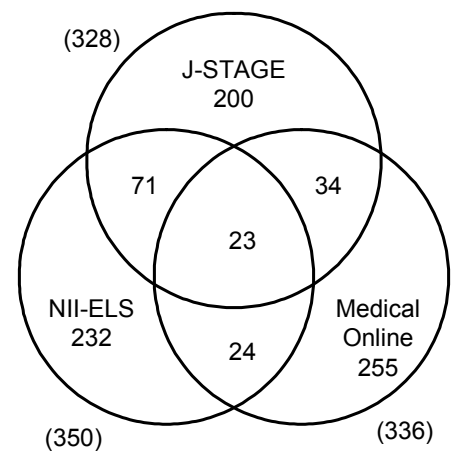

図3＼cjkstart国内3サイトの全雑誌（839 誌）の重複状況

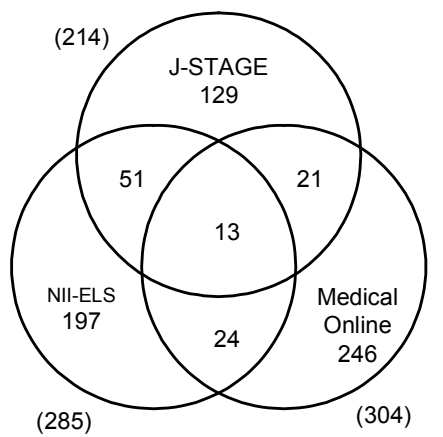

国内3サイトの和文誌 /和英混載誌（681誌）の重複状況

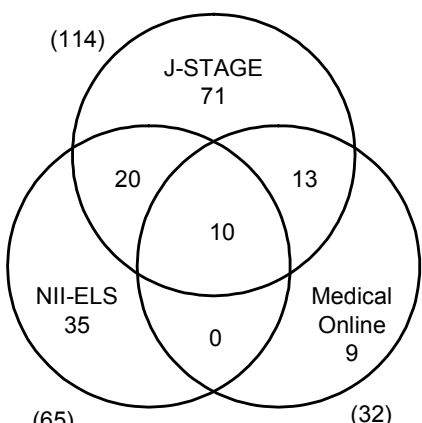

(65)

(32)

図5＼cjkstart国内3サイトの英文誌（158 誌）の重複状況

表10 国内および海外電子ジャーナルサイトの登載雑誌数

\begin{tabular}{|c|c|c|c|c|c|c|c|}
\hline & \multirow{2}{*}{$\begin{array}{c}\text { 雑誌 } \\
\text { 少ト } \\
\text { 掲載数 }\end{array}$} & \multirow{2}{*}{$\begin{array}{l}\text { 科学 } \\
\text { 技術 } \\
\text { 医学 } \\
\text { 分野 }\end{array}$} & \multirow[t]{2}{*}{ 論文誌 } & \multirow{2}{*}{$\begin{array}{l}\text { 論文誌 } \\
\text { (除大学発 } \\
\text { 行) }\end{array}$} & \multicolumn{3}{|c|}{$\begin{array}{l}\text { 2005年時点発行中 } \\
\text { 論文誌 }\end{array}$} \\
\hline & & & & & 合計 & $\begin{array}{l}\text { 和文誌. } \\
\text { 混載誌 }\end{array}$ & 英文誌 \\
\hline NII-ELS & 5,559 & 2,915 & 733 & 473 & 350 & 285 & 65 \\
\hline J-STAGE & 380 & 370 & 364 & 343 & 328 & 214 & 114 \\
\hline MedOnline & 565 & 556 & 380 & 345 & 336 & 304 & 32 \\
\hline 国内計 * & & & & & 839 & 681 & 158 \\
\hline 海外出版社 & 147 & 143 & 138 & 136 & 125 & 1 & 124 \\
\hline \multicolumn{5}{|c|}{ 電子ジャ一ナル総数 * } & 949 & 682 & 267 \\
\hline \multicolumn{5}{|l|}{ 論文誌総数 } & 2,655 & 2,304 & 351 \\
\hline \multicolumn{5}{|c|}{ 電子ジャーナルの割合 (\%) } & 35.7 & 29.6 & 76.1 \\
\hline
\end{tabular}

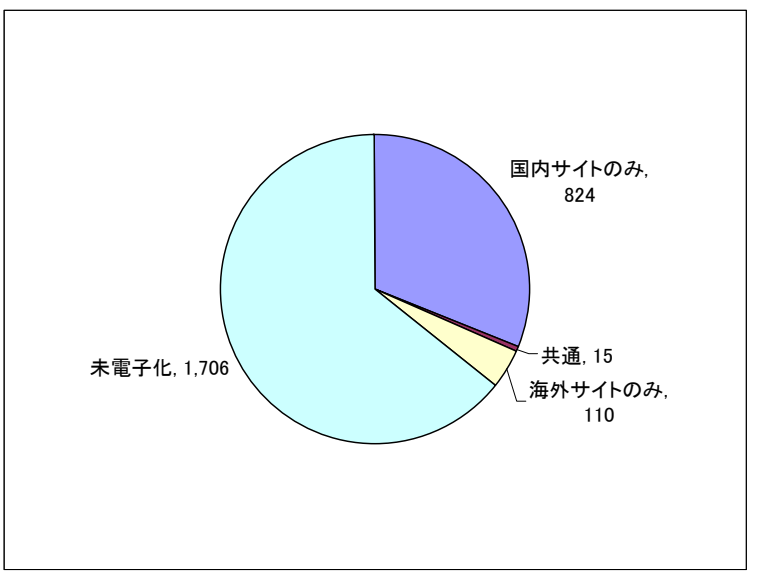

図6＼cjkstart電子ジャーナルの国内サイトと海外サイトの 登載数の分布 (全雑誌)

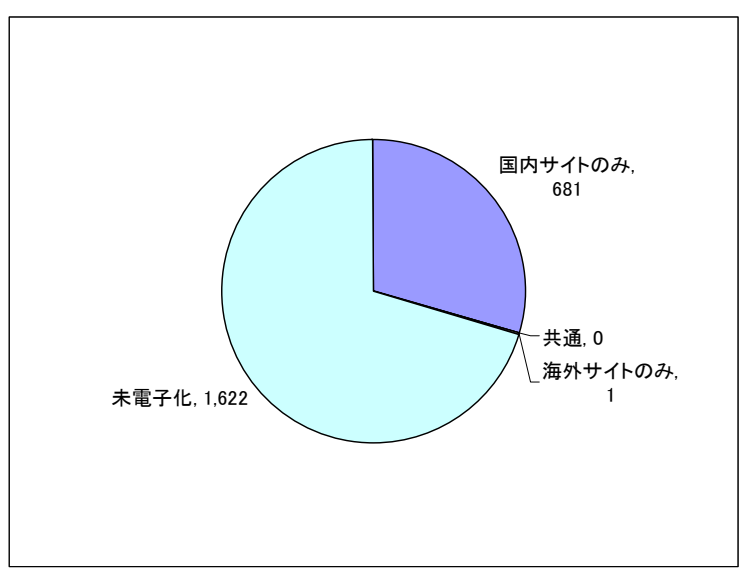

図7＼cjkstart電子ジャーナルの国内サイトと海外サイトの 登載数の分布 (和文・混載誌)

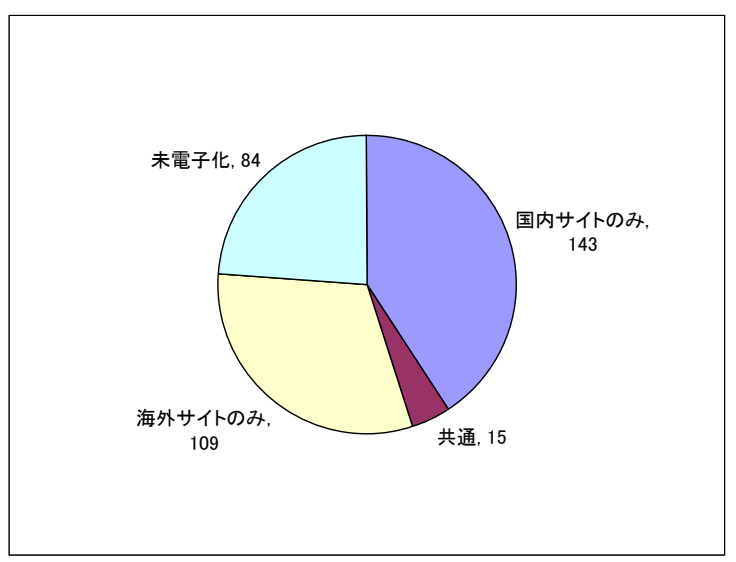

図8＼cjkstart電子ジャーナルの国内サイトと海外サイトの 登載数の分布 (英文誌) 
称していたが，2008年6月よりこの名称となった。 一部売り (pay-per-view)。

この分析では，各種データのそろっている2005 年時点について比較することとした。PierOnlineと MedicalFinderは2005年時点では本格的なサービス は行っていなかったので，以下の分析には含めな かった。この他にも学会独自に電子ジャーナルと して公開している雑誌もあるが，今回の調査には 含めていない。2005年時点で発行されている論文 誌（大学等発行を除いたもの）は2,899誌中2,655 誌であった。

J-STAGE，NII-ELS，メディカルオンラインの3サ イトと海外電子ジャーナルサイトの日本発行の雑 誌数は表10のとおりであった。また比較のため日 本の学協会発行誌等で海外出版社から発行されて いる雑誌の数も示した。ここで「論文誌」は大学・ 研究所等が発行している論文誌を除いた，主とし て学協会が発行している論文誌を指している。ま た「英文誌」とはすべての論文が英文であるもの

表11 電子ジャーナル3サイトに共通して登載されていた雑誌

\begin{tabular}{|c|c|c|}
\hline ISSN & 雓誌名 & 出版者名 \\
\hline $0009-2363$ & Chemical \& Pharmaceutical Bulletin & Pharmaceutical Society of Japan \\
\hline $0031-6903$ & 薬学雑誌 & 日本薬学会 \\
\hline $0034-351 x$ & リハビリテーション医学 & 日本リハビリテーション医学会 \\
\hline $0368-5829$ & 杏林医学会雑誌 & 杏林医学会 \\
\hline $0385-0110$ & 日本歯周病学会会誌 & 日本歯周病学会 \\
\hline $0385-5481$ & 行動計量学 & 日本行動計量学会 \\
\hline $0385-7417$ & Behaviormetrika & 日本行動計量学会 \\
\hline 0449-3060 & Journal of Radiation Research & Japan Radiation Research Society \\
\hline $0470-8105$ & Neurologia Medico-Chirurgica & 日本脳神経外科学会 \\
\hline 0910-0865 & 環境変異原研究 & 日本環境変異原学会 \\
\hline $0914-5508$ & 脳卒中の外科 & 日本脳卒中の外科学会 \\
\hline 0918-5739 & Clinical Pediatric Endocrinology & 日本小児内分泌学会 \\
\hline $0918-6158$ & Biological \& Pharmaceutical Bulletin & Pharmaceutical Society of Japan \\
\hline $1341-0725$ & 産業衛生学雑誌 & 日本産業衛生学会 \\
\hline 1341-9145 & Journal of Occupational Health & Japan Society for Occupational Health \\
\hline $1342-078 \mathrm{X}$ & $\begin{array}{l}\text { Environmental Health and Preventive } \\
\text { Medicine }\end{array}$ & 日本衛生学会 \\
\hline $1343-2826$ & Kitakanto Medical Journal & 北関東医学会 \\
\hline $1344-9702$ & Journal of Health Science & 日本薬学会 \\
\hline $1345-3475$ & $\begin{array}{l}\text { Journal of Physiological Anthropology } \\
\text { and Applied Human Science }\end{array}$ & 日本生理人類学会 \\
\hline $1348-589 \mathrm{X}$ & Journal of Pesticide Science & 日本農薬学会 \\
\hline $1348-9615$ & 日本再生歯科医学会誌 & 日本再生歯科医学会 \\
\hline $1348-9623$ & Journal of Oral Tissue Engineering & 日本再生歯科医学会 \\
\hline 1349-0079 & Journal of Oral Biosciences & 歯科基硴医学会 \\
\hline
\end{tabular}

を指し，例えば隔号で英文誌が発行されるような もの (Journal of Mammalian Ova Researchなど) は混 載誌とした。

「現在発行中」とは2005年時点に発行されてお り, かつ各サイトに収録されている雑誌のことで あり，それより前に廃刊・休刊となったり誌名が 変更されたもの, あるいはその後にサイトに追加 されまたは新規に発行された雑誌は含まれてい ない。発行期間の確認は主として前記NDL-OPACに よって行った。

筆者の口頭発表 ${ }^{16)}$ においては大学発行の雑誌を 除いていなかったため, NIIIELSの登載誌数が飛び抜 けて大きかったが, これを除いたことにより，各 サイトの登載誌数はほぼ同等となった。

すなわち2005年時点で発行されていた論文誌 2,655誌の35.7\% (949誌) が電子化されて提供され ていることになるが, 英文誌については76.1\%と高 く，かなりのものがすでに電子化されていること がわかった。しかし和文誌については電子化率は まだまだ低い (29.6\%)。

また，国内3サイトについて雑誌の重複状況は 図3のようになった。

これら3サイトに共通して登載されていた雑誌 は表11のとおりである。

これらにより, 各雑誌の重複状況はあまり大き くなく, それぞれ独自の雑誌を登載していると考 えられる。和文誌・混載誌についてはメディカル オンライン, NII-ELS, J-STAGEの順に登載誌が多く, 英文誌についてはこの逆の順となっている。

電子ジャーナルについて国内サイトと海外サイ トの収録の分布を見たのが図6-8である。

このように，和文・混載誌は海外サイトにはほ とんど登載されていないが，英文誌については国 内サイトへの登載がやや上回っているものの, か なりの英文誌が海外出版社から発行されているこ とがわかる。 


\section{参考文献}

1) 倉田敬子. 学術情報流通とオープンアクセス. 勁草書房. 2007, p.55-57.

2) Tenopir, Carol. Online Databases - Online Scholarly Journals: How Many? Library Journal. 2004-02-01. http://www.libraryjournal.com/article/CA374956.html, (accessed 2008-03-05).

3) Ulrich's Serials Analysis System. http://www.ulrichsweb.com/ulrichsweb/usasfaq.asp, (accessed 2008-03-04).

4) Mark Ware Consulting Ltd. "Scientific publishing in transition: an overview of current developments". September 2006, 30p. http://www.alpsp.org/ForceDownload.asp?id=127, (accessed 2008-03-04).

5) 時実象一. 中国における電子ジャーナルの現状. 情報管理. 2007, vol.50, no.1, p.2-10.

6) 国立国会図書館. NDL-OPAC: 検索できる資料. http://opac.ndl.go.jp/Process?MODE_10260001\&LS=7128013138\#about, (参照2008-03-04).

7) 国立国会図書館. 日本科学技術逐次刊行物総覧. http://refsys.ndl.go.jp/E001_EP01.nsf/Public?OpenFrameset, (参照2008-03-04).

8) 上田修一, 出羽美子, 倉田敬子. 海外主要データベースにおけるわが国科学技術雑誌の収録状況. ドク メンテーション研究, 1983, vol.33, no.9, p.421-430.

9) Ikushima, K.; Tenopir, C. Availability of Japanese scientific and technical periodicals in major english language databases. Proceedings of the Ninth National Online Meeting. 1988, p.115-122.

10）原田郁子. JST収集・収録誌と海外主要データベース収録誌との比較. 情報管理. 2004, vol.47, no.2, p. 96-101.

11) 殿崎正明. PubMedに収録されている日本の雑誌: 最近3年間の調査分析. オンライン検索. 2006, vol.27, no.2, p.95-105.

12) Jacso, Peter. Analyzing the journal coverage of abstracting/indexing databases at variable aggregate and analytic levels. Library and Information Science Research. 1998, vol.20, no.2, p.133-151.

13) Gluck, Myke. A Review of Journal Coverage Overlap with an Extension to the Definition of Overlap. Journal of the American Society for Information Science. 1999, vol.41, no.1, p.43-60.

14) VanLeeuwen, Thed N.; Moed, Henk F.; Tijssen, Robert J. W.; Visser, Martijn S.; VanRaan, Anthony F. J. Language biases in the coverage Science Citation Index and its consequences for international comparisons of research performance. Scientometrics. 2001, vol.51, no.1, p.335-346.

15) Moya-Anegon, Felix De; Chinchilla-Rodriguez, Zaida; Vargas-Quesada, Benjamin; Corera-Alvarez, Elena; MunozFernandez, Francisco Jose; Gonzalez-Molina, Antonio; Herrero-Solana, Victor. Coverage analysis of Scopus: A journal metric approach. Scientometrics. 2007, vol.73, no.1, p.53-78.

16）時実象一. 日本発行雑誌の各種科学技術医学データベースへの収録状況. 第3回情報プロフェッショ ナルシンポジウム予稿集. 2006, p.75-78, http://www.jstage.jst.go.jp/article/infopro/2006/0/75/_pdf/char/ja/, (参照2008-03-04).

17) 国立国会図書館. NDL-OPAC. http://opac.ndl.go.jp/, (参照2008-03-04).

18）国立情報学研究所. NACSIS Webcat. http://webcat.nii.ac.jp/, (参照2008-03-04). 


\section{著者抄録}

各種雑誌リストを用いて日本で発行されている科学技術医学系雑誌の数を調査したところ，論文誌2,899 誌，大学等論文誌603誌，大学紀要2,886誌であった。うち英文誌はそれぞれ416誌，83誌，33誌であった。 論文誌のうち2005年に実際に発行されていたもの2,655誌のうち949誌 (35.7\%) が何らかの形でオンライ ン化されていた。またそのうちの英文誌は351誌で，うち267誌 (76.1\%) がオンライン化されていた。主 な電子ジャーナルサイトNIIIELS，J-STAGE，メディカルオンラインの収録誌を比較した。

キーワード

学術雑誌, 電子ジャーナル, 論文誌, 英文誌, NII-ELS, J-STAGE, メディカルオンライン

\section{Author Abstract}

The number of scholarly journals published in Japan in the fields of science, technology and medicine was determined using various journal lists. There were 2,899 scholarly journals, 603 university journals, and 2,886 university bulletins published in Japan. Specifically 2,655 scholarly journals were actively published in 2005, including 351 English-language journals. Among them, 949 journal titles were already online, including 267 English-language journals.

\section{Key words}

scholarly journals, electronic journals, peer-reviewed journals, English-language journals, NII-ELS, J-STAGE, Medical Online 